\title{
Total Insurance Inc.: Application Of ABC Management Concepts For Evaluation Of Sales Teams
}

\author{
Ali M. Sedaghat, DBA, CMA, Loyola University Maryland, USA \\ A. Kim Sherman, PhD, Loyola University Maryland, USA \\ Thomas Carroll, President, Diversified Insurance Industries, Inc., USA
}

\begin{abstract}
Total Insurance, Inc. (TII) is an instructional case to expand students' understanding of potential benefits of $A B C$ beyond traditional manufacturing applications rather than as a technical $A B C$ application exercise. It does not require complex calculations, yet it allows instructors to discuss why companies may adopt some $A B C$ concepts and demonstrates the process by which they create and develop the information to build the system. Jack White was the CEO of TII, a successful independent insurer. Several major insurance providers, such as Travelers, Erie, and The Hartford, rely on independent agents around the nation to sell and service their policies. The company acted like a broker between the insurance providers and the customers, but it is truly an agent of the insurance provider in each transaction. The company handled $\$ 100$ million in premium volume, mostly from commercial insurance (\$86 million) with very different apparent performances from their sales force teams. The teams of one or two sales producers had one to five other employees and drew differently from the common resources of the firm. He was having trouble distinguishing which of his sales teams were contributing most to his bottom line. He particularly needed this information in order to help the sales teams to improve their own productivity. White, recalling an accounting course he had taken in his Executive MBA program, decided to investigate the ability of $A B C$ analysis, as applied in that course toward evaluating customers, to gather data on cost drivers and resource use to determine the productivity of his sales teams.
\end{abstract}

Keywords: ABC Management, Insurance Industry, Performance Evaluation of Sales Teams

\section{INTRODUCTION}

$\varnothing$ ack White found himself explaining to a friend at a cocktail party what he thought were the key elements of his success as the CEO of one of the most prosperous independent insurance agencies in the mid-Atlantic region of the U.S. He cited the teamwork atmosphere that the company had developed, and expressed the feeling that he had chosen excellent people to join him at Total Insurance, Inc. (TII). However, he admitted that he had trouble distinguishing which of his sales teams were contributing most to his bottom line. Like many agencies that he knew, he had developed teams within the agency to which he provided leadership and common services. TII's teams of one or two sales producers had one to five other employees and drew differently from the common resources of the firm. His conversation ended with White wondering if he could effectively answer the question of which of his teams were the most productive in terms of net profit to the organization.

He recalled managerial accounting courses he had taken and cases he had studied in his Executive MBA studies at Loyola University Maryland. He remembered how Activity Based Costing (ABC) was cited as particularly effective at identifying the costs and cost drivers that impact profitability and wondered if he could put the concept, methodologies and data together to get a better picture of the profitability of his sales teams. 


\section{THE INSURANCE INDUSTRY}

Many insurance companies rely on a nationwide network of independent agencies and brokers to sell their products. Unlike the captive agents who are employees of an insurance company or telephone sales representatives, independent insurance agents and brokers are separate entities and represent an average of eight different insurance companies. (See Exhibit 1 for an overview of the commercial insurance distribution system.) This allows them to research these firms to find their clients the best combination of price, coverage, and service. The law is not clear as to whether the independent insurance agent has a fiduciary responsibility to act in the customer's interest. In fact, the word "agency" itself would indicate that the independent agent's primary attachment is to the carrier (http://www.disasterprepared.net/fiduciary.html - Accessed 6/30/09). Exhibit 1 shows the distinctions among the general types of insurance providers.

Exhibit 1: Commercial Insurance Distribution System

\begin{tabular}{|l|l|l|l|}
\hline \multicolumn{1}{|c|}{ Type of Service } & \multicolumn{1}{c|}{ Customer Contact } & \multicolumn{1}{c|}{ Products } & \multicolumn{1}{c|}{ Carrier Examples } \\
\hline Direct from carrier & $\begin{array}{l}\text { Carrier office or HQ or by } \\
\text { phone or Internet }\end{array}$ & Any coverage that carrier provides & $\begin{array}{l}\text { GEICO } \\
\text { Progressive }\end{array}$ \\
\hline Captive agency & $\begin{array}{l}\text { Local agency under franchise } \\
\text { agreement }\end{array}$ & Any coverage that carrier provides & $\begin{array}{l}\text { State Farm } \\
\text { Allstate }\end{array}$ \\
\hline $\begin{array}{l}\text { Independent agency or } \\
\text { broker }\end{array}$ & Local agency & Any coverage by any carrier & $\begin{array}{l}\text { The Hartford } \\
\text { Travelers }\end{array}$ \\
\hline
\end{tabular}

The insurance companies (also known as carriers or underwriters) are the product providers who issue policies and assume risk in exchange for premiums. The insurance industry is a global business. Worldwide premiums exceeded \$3 trillion in 2006. In the United States, which accounts for about 34 percent of the world's insurance business, premiums are more than $\$ 1$ trillion per year. The U.S. insurance industry employs more than two million workers, about 2.1 percent of the nation's workforce (http://www.bls.gov/oco/cg/cgs028.htm\#emply accessed 6/29/09).

In the U.S., the insurance business is generally viewed as three distinct segments; property/casualty, life, and health. The property/casualty segment of the industry provides insurance for cars, homes, and businesses. Property/casualty insurance can be broken down into two major categories: commercial lines of insurance and personal lines. Personal lines, as the term suggests, include coverage for individuals, such as automobile and homeowners insurance. Commercial lines, which account for more than half of U.S. property/casualty insurance premiums, include many kinds of insurance designed to protect businesses. Commercial insurance performs a critical role in the world economy. Commercial insurers assume the risks inherent in the production and distribution of goods and services. This transfer of risk protects insured companies from catastrophic losses and potential financial ruin that could result from an accident, mistake, or natural disaster. The ability of commercial insurers to guarantee the stability of the U.S. and world corporations was challenged in the monetary crisis and serious recession of 2008-2009.

\section{FINANCIAL REPORTING}

Insurers in all states are required to use a special accounting system when filing annual financial reports with state regulators. This system is comprised of and named for its statutory accounting principles (SAP). SAP accounting is more conservative than generally accepted accounting principles (GAAP), as defined by the Financial Accounting Standards Board, and is designed to help ensure that insurers have sufficient capital and surplus to cover all anticipated insurance-related obligations (http://www.investopedia.com/terms/s/sap.asp - accessed 6/29/09). The two systems differ principally in matters of timing of expenses, tax accounting, the treatment of capital gains, and accounting for surplus. Simply put, SAP recognizes liabilities earlier or at a higher value, while also recognizing assets later or at a lower value. GAAP accounting focuses on a business as a going concern, while SAP accounting treats insurers as if they were about to be liquidated. SAP accounting is defined by state law according to uniform codes established by the National Association of Insurance Commissioners. Insurance companies reporting to the Securities and Exchange Commission must also maintain and report a financial reports that meet GAAP standards. 


\section{TOTAL INSURANCE, INC}

Total Insurance, Inc. (TII) was established in 1969 by Jack White. White immigrated to the United States in 1951 as an orphan. Following a stint in the United States Army, he found a job as a personal automobile policy underwriter. He later became the business manager and leading salesperson of another insurance agency before leaving to start TII. From modest beginnings, TII has become the $3^{\text {rd }}$ largest privately owned commercial insurance agency in the Baltimore region (growing from $\$ 300,000$ to more than $\$ 100$ million in annual premium volume). With a staff of more than 90 insurance professionals, TII serves the Mid-Atlantic region and offers a full complement of insurance products: commercial property and casualty; homeowners, car and boat: surety bonds; professional liability; term, universal and whole life; and health insurance. Exhibit 2 provides some key financial measures between the TII and the industry.

Exhibit 2: TII Performance In comparison with the Industry Benchmarks

\begin{tabular}{|l|c|c|c|}
\hline \multicolumn{1}{|c|}{ Measurements } & Average & Top 25\% & TII \\
\hline Current Ratio & 1.24 & 1.78 & 1.59 \\
\hline Tangible Net Worth & $4.20 \%$ & $25.10 \%$ & $30.57 \%$ \\
\hline Receivable/Payable Ratio & $48.70 \%$ & $10.50 \%$ & $27.52 \%$ \\
\hline & & & $\$$ \\
\hline Revenue Per Employee & $\$ 160,361.00$ & $\$ 180,355.00$ & $\mathbf{\$ 1 1 3 , 2 2 4 . 5 7}$ \\
\hline Compensation Per Employee & $\$ 105,938.00$ & $\$ 103,856.00$ & $\mathbf{\$ 5 1 , 2 1 6 . 6 1} \%$ \\
\hline Employee Marginal Profitability & $\$ 54,423.00$ & $\$ 76,499.00$ & $\mathbf{\$ 6 2 , 0 0 7 . 9 6}$ \\
\hline & & & $2.67 \%$ \\
\hline IT Expense as a \% of Revenue & $1.80 \%$ & $1.80 \%$ & $\mathbf{3 7 . 0 2 \%}$ \\
\hline Non-Payroll Expenses as a \% of Revenue & $31.13 \%$ & $29.10 \%$ & $17.34 \%$ \\
\hline Support Personnel as a \% of Total Revenue & $18.28 \%$ & $17.40 \%$ & \\
\hline
\end{tabular}

*TII's sales people were equity holders in the company and were otherwise compensated on a commission-only basis, which is not typical in the industry.

The company is organized into three operating departments-commercial insurance, personal insurance and employee benefits. The commercial insurance department, which constitutes 90 percent of TII's revenues, is divided into 18 sales teams that support 24 independent sales agents (or producers). Forty-two (42) direct support staff members are assigned to the sales teams and have generally been allocated purely on the basis of premium volume. In addition, there are 15 indirect support staff providing administrative, secretarial, billing, information technology and service functions to all sales teams.

\section{THE TII PROBLEM}

Although TII is one of Maryland's most successful privately held insurance agencies, it has managed to operate for the past 38 years without any formal cost accounting system. There are many common business decisions that have been difficult to address due to the lack of a cost allocation system. These issues include:

- $\quad$ Measuring the profitability of sales teams

- $\quad$ Allocating agency financial and human resources to sales teams

- $\quad$ Predicting and planning for future resource requirements

- $\quad$ Evaluating the profitability of key customers or customer segments

Jack White decided to apply Activity Based Costing (ABC) to address these issues. He was most concerned about his commercial insurance department which represented ninety percent of his agency's revenue, so he began the process of identifying what would be necessary for an $\mathrm{ABC}$ analysis of this part of the business.

White recognized that, typically, activity based costing (ABC) first assigns costs to the activities that are the real cause of the overhead. It then assigns the cost of those activities only to the cost objects that are actually demanding/using the activities. In his case he considered the sales team to be the cost object and he would like to 
apply the same principles to allocate his overall expenses to the sales teams. He recognized that this is not a typical $\mathrm{ABC}$ used in manufacturing firms, where the company categorizes its activities into Unit level, batch level, product level and capacity sustaining level. He thought that the cases where service companies used $A B C$ for measuring customer profitability were closer to meeting his needs.

White decided that he needed to implement his plan by taking the following systematic steps.

1. Gather annual data by sales person and by team.
a. Sales
b. Income
c. Activities (e.g. transactions)

2. Analyze annual company expense data and determine whether expenses are fixed or variable
a. $\quad$ Fixed Expenses - determine an equitable allocation method
b. Variable Expenses - evaluate possible cost drivers to see which of them best predict and measure expense development

3. Develop most important cost drivers for cost allocation
a. Determine the most rational and predictive cost driver for each expense
b. $\quad$ Assign cost drivers to individual expense categories
c. Calculate a per unit cost for each expense category

4. Establish a financial statement that allocates costs and profits by sales team
a. Input sales data from Step 1
b. $\quad$ Calculate expense items by sales teams using the drivers calculated in Step 3c

5. Assess the reasonableness of the results and reassess if necessary

White was able to secure sales, income and activity data directly from the management accounting system of TII. He selected six of the teams to reduce the total analytical work load and categorized the data by sales team. Exhibit 3 summarizes some of the costs and revenues attributable to six of his teams.

Exhibit 3: Summary Data on Costs and Revenues Associated With Six Representative TII Teams

\begin{tabular}{|l|l|l|l|l|l|l|}
\hline & AMcD & BH & LAS & DiP & WC & MDD \\
\hline Premium Volume & $\$ 8,797,507$ & $\$ 5,012,435$ & $\$ 1,050,329$ & $\$ 10,031,291$ & $\$ 6,396,396$ & $\$ 8,420,663$ \\
\hline \# of Producers* & 2.0 & 1.0 & 1.0 & 2.0 & 1.5 & 1.0 \\
\hline \# of Transactions & 2071.0 & 1263.0 & 587.0 & 2866.0 & 1799.0 & 919.0 \\
\hline \# of Employees* & 5.00 & 3.00 & 1.80 & 3.85 & 4.50 & 1.00 \\
\hline Gross Commission Income & $\$ 921,602$ & $\$ 418,539$ & $\$ 198,459$ & $\$ 958,592$ & $\$ 711,471$ & $\$ 696,267$ \\
\hline Less: Commission's Paid & $-\$ 414,721$ & $-\$ 188,343$ & $-\$ 89,307$ & $-\$ 431,366$ & $-\$ 320,162$ & $-\$ 313,320$ \\
\hline Agency Revenue & $\$ 506,881$ & $\$ 230,196$ & $\$ 109,152$ & $\$ 527,226$ & $\$ 391,309$ & $\$ 382,947$ \\
\hline Unit Payroll & $\$ 233,360$ & $\$ 162,800$ & $\$ 57,905$ & $\$ 187,148$ & $\$ 234,292$ & $\$ 50,980$ \\
\hline Shared Payroll & $\$ 77,314$ & $\$ 47,150$ & $\$ 21,914$ & $\$ 106,993$ & $\$ 67,160$ & $\$ 34,308$ \\
\hline Total Payroll & $\$ 310,674$ & $\$ 209,950$ & $\$ 79,819$ & $\$ 294,141$ & $\$ 301,452$ & $\$ 85,288$ \\
\hline & & & & & & \\
\hline Departmental Margin & $\$ 196,207$ & $\$ 20,246$ & $\$ 29,334$ & $\$ 233,085$ & $\$ 89,857$ & $\$ 297,659$ \\
\hline Sales margin $\%$ & $38.71 \%$ & $8.80 \%$ & $26.87 \%$ & $44.21 \%$ & $22.96 \%$ & $77.73 \%$ \\
\hline
\end{tabular}

* Fractional people indicate shared resources or part-time employees.

From the accounting system of TII, he was able to produce an annual summary of expenses. These expenses were grouped by category. All expenses were common to a sales and service organization. Throughout the process, he attempted to use logic that was consistent with his accounting lessons. He started by evaluating TII's expenses to determine if they were fixed or variable costs, which were used in making his decisions about the most rational way to allocate these costs. 


\section{COST DRIVERS}

This was one of the most important elements of the project. He evaluated numerous potential drivers that were relevant to the insurance industry. He endeavored to determine which of these potential drivers would help him allocate costs in the most rational and predictive manner. Ultimately there were only a handful of logical cost drivers (listed in the Exhibit 4). He used this list to select a cost driver for each expense category and then calculated the per-unit cost for each expense.

Exhibit 4: TII Cost Drivers

\begin{tabular}{|l|c|}
\hline \multicolumn{1}{|c|}{ TII Cost Drivers } & 24 \\
\hline Number of Producers & 42.15 \\
\hline Number of Employees & $\$ 85,875.40$ \\
\hline Premium Volume (in \$1,000) & 21,720 \\
\hline Number of Transactions & \\
\hline
\end{tabular}

Note: See Appendix 1 for a listing of the expense categories and appropriate cost drivers and Appendix 2 for the per unit costs values for each expense category.

\section{DEVELOPMENT OF COST DRIVERS}

1. Number of Producers (Sales People): He used the number of sales people to classify certain expenses. For example, advertising expenses benefit each producer equally in their ability to win customers, therefore it was determined that advertising costs were variable based on the number of producers, even though an additional producer wouldn't increase advertising costs.

2. Number of Employees: The number of direct support employees proved to be a good measure of other expense types. For example, rent expense was best measured by the number of people assigned to each sales unit - as the number of people changes, space requirements change proportionally.

3. Premium Volume (Total Sales Dollars): Premium volume was used to measure expenses that vary in proportion to sales, for example, company insurance for "errors and omissions" is based largely on sales volume.

4. Number of Transactions (Policies Serviced): The number of transactions was an accurate cost driver for expenses linked to the processing of policies, such as courier fees, office supplies and telephone expense.

The purpose of Activity-Based Costing is to provide management a clear picture of the cost structure of their organization. There are numerous strategic decisions that will be impacted by the results of this project. With an accurate picture of the costs and the activities that drive cost, management can then develop a plan to control costs and reduce or eliminate redundancy from the system.

Underperforming sales teams will be challenged to increase output or face cost constraints. Sales people who focus on unproductive clients will be challenged and trained to pursue more profitable sales activities. Future resource allocation decisions will be aided by an accurate picture of existing resource commitments. This will help to ensure that resources are dedicated to productive, profitable areas.

As White began to see how his system might work, he designed a memorandum (Exhibit 5)to send to his sales teams when he had a good sense of whether his system would help form performance criteria that would help TII to assist the sales teams in making choices that will increase the profitability of the company. 
Exhibit 5: Jack White's Draft Memorandum to Team Leaders

\begin{tabular}{ll}
\hline To: & The Executive Team \\
From: & Jack White \\
CC: & [Recipient names deleted - privacy] \\
Date: & TBD \\
Re: & Performance Management
\end{tabular}

Comments: The purpose of this memorandum is to outline some thoughts around the difficulty we have been experiencing with the issue of performance management among our sales teams. We have struggled to find an effective manner to judge each team, and every time we try to implement a measurement system we seem to come up against opposition; and often these criticisms are warranted.

It would be nice to set expectations in very simple terms; however, every time we try that, we run up against the same issues and complaints. Sales teams complain that their circumstances are different than others and they have more work than the other teams. "In order for me to grow, I need more help." Add to that the fact that our structure also makes it difficult to impose a standard of performance. Sales people who own their books of business are reluctant to accept external pressure for additional sales activity. On the other hand, good business requires the correct allocation of resources, and growth efforts require capacity. Because our sales people own their clients and get paid strictly on a commission basis, you might think that there is every incentive in the world to constantly be growing. And maybe there is; however, even the desire to grow is impacted by the capacity to do the work necessary to grow. I see it as essential to develop a financial model that gives us an accurate picture of what is really going on so we can discern the real barriers to growth, identify capacity and subsequently expectations that tie into our growth objectives. Simplistic evaluations have left us wanting for a methodology that truly measures our situations.

We always know the top and the bottom performers. The top rarely need much in the way of encouragement or objectives. Rather they clamor for accountability among the lower performers. At the other end, the bottom performers are typically easy to see and their issues are commonly due to capability rather than the lack of specific objectives. It is the middle performers that perplex me. If we can develop a performance standard for this group that provides accurate insight, then we can make decisions on how to allocate resources to their improvement. Tools like training, mentoring and support can be applied appropriately. This situation can't be a completely unique. I sometimes wonder if the evaluation of sales performance in our organization is similar to the challenge faced by a multi-location retail organization. For example, what to do when you have two stores generating similar sales levels in similar geographic territories.

The real challenge is to make sense of the complexity in comparing two books of business. When I look at the data that we generate when we allocate expenses based on revenue I intuitively know that some of the results are skewed. When I take two salespeople with nearly identical revenue yet a completely different number of clients served, the complexity begins. Add to this the ability to transfer some work to our insurance carrier partners and the impact on our activity, the complexity is expanding. Other factors include marketing/re-pricing activity, billing activity/accuracy, certificate of insurance (verification of coverage) to name a few. Our salespeople love to point out the unique demands of their book of business when we discuss their growth challenges. I am reminded of a management paradox - attribution error. When I cut into traffic it is because I am running late for a very important meeting. When I get cut off, it is because of the character flaws of the other driver. We believe our behavior is driven by circumstance and the behavior of others is driven by their character. Proper sales management eliminates this paradox.

Based on the knowledge I gained in the Executive MBA program and, especially, in Managerial Accounting, I believe we may be able to apply a cost analysis tool to build the requisite bridge. Proper cost allocation will allow us to create a method to break through the complexity of evaluating a book of business to see what impact different activities have on our ability to create bandwidth to grow. Once we have a clear picture of our reality, then we can establish benchmarks for performance and create incentives for our sales teams to grow. This will enable us to align their desire for support with our need to increase our number of customers and revenue. It should also help us better define ideal clients. 


\section{QUESTIONS}

1. How does TII compare with other companies in its industry?

2. Organizations are always looking for ways to improve their profitability, but what do you think prompted TII use $\mathrm{ABC}$ to evaluate team performance?

3. What additional steps should have been considered to confirm/ justify the selection of the cost drivers listed in Appendix 1

4. Apply $\mathrm{ABC}$ to measure the profitability of the sales teams by using the selected expenses and cost drivers from Appendix 1.

\section{AUTHOR INFORMATION}

Dr. Ali M. Sedaghat, CMA, is associate professor of accounting at Loyola University Baltimore, where he has taught accounting courses for 24 years. He is a member of the American Accounting Association, Institute of Management Accounting, and the Decision Science Institute He has published in Issues in Accounting Education, Advances in Accounting, Accounting Educators Journal, The Journal of Teaching in International Business , Journal of Corporate Taxation, The Business \& Taxes Quarterly, Management Accounting and Journal of International Accounting, and presented papers at more than thirty national and international professional meetings

Dr. A. Kimbrough Sherman is an associate professor of Operations Management at Loyola University, Maryland where he has taught for 35 years. He earned his bachelor's degree in Economics at Brown University and his MBA in Operations Management and his PhD in Economics/Operations Research from the University of Maryland. He has served as a consultant to the states of Illinois and Maryland on economic development and to many not-forprofits on strategy and processes. His principal research areas are in systems analysis, process improvement, and implementation of the Metric System (SI).

Thomas E. Carroll is the President of Diversified Insurance Industries, Inc. since 2004. He earned a BS from Towson University in Accounting and Finance and an Executive MBA from Loyola University Maryland and is a graduate of the Entrepreneur Development Center at the University of Maryland University College. He participates on many insurance advisory boards and is active in the local community. 


\section{APPENDIX 1}

Expense Categories and Relevant Cost Drivers

\begin{tabular}{|c|c|c|c|}
\hline $\begin{array}{r}\text { Expense } \\
\end{array}$ & Absolute Expense & Direct/Indirect & Cost Driver \\
\hline Advertising & $\$ 5,500.00$ & Indirect & \# of Producers \\
\hline Amortization & $\$ 20,200.00$ & Indirect & Premium Volume \\
\hline Automobile Expense & $\$ 35,000.00$ & Direct & Traceable \\
\hline Computer Maintenance & $\$ 75,000.00$ & Indirect & \# of Employees \\
\hline Depreciation & $\$ 32,500.00$ & Indirect & \# of Employees \\
\hline Donations & $\$ 12,000.00$ & Indirect & \# of Producers \\
\hline Education & $\$ 35,000.00$ & Indirect & \# of Employees \\
\hline Entertainment & $\$ 25,000.00$ & Indirect & \# of Producers \\
\hline Equipment Maintenance & $\$ 13,000.00$ & Indirect & \# of Employees \\
\hline Accounting Fees & $\$ 101,500.00$ & Indirect & \# of Transactions \\
\hline Legal Fees & $\$ 13,000.00$ & Indirect & Premium Volume \\
\hline Other Professional Fees & $\$ 25,000.00$ & Indirect & Premium Volume \\
\hline Insurance & $\$ 150,000.00$ & Indirect & Premium Volume \\
\hline Medical Insurance & $\$ 175,600.00$ & Indirect* & \# of Employees \\
\hline 401K Expense & $\$ 23,086.50$ & Indirect* & \# of Employees \\
\hline Office Supplies & $\$ 88,150.00$ & Indirect* & \# of Transactions \\
\hline Life Insurance & $\$ 15,000.00$ & Direct & Traceable \\
\hline Payroll Taxes & $\$ 425,000.00$ & Indirect* & Total Payroll \\
\hline Postage & $\$ 35,000.00$ & Indirect & \# of Transactions \\
\hline Courier & $\$ 13,023.00$ & Indirect & \# of Transactions \\
\hline Rent & $\$ 325,000.00$ & Indirect & \# of Employees \\
\hline Temp Salaries & $\$ 2,500.00$ & Indirect & Traceable \\
\hline Taxes \& Licenses & $\$ 25,000.00$ & Indirect & Premium Volume \\
\hline Telephone & $\$ 50,000.00$ & Indirect & \# of Transactions \\
\hline Travel & $\$ 10,000.00$ & Indirect & \# of Producers \\
\hline Bad Debts & $\$ 1,000.00$ & Indirect & Allocate/ Traceable \\
\hline Unit Payroll & $\$ 2,115,246.00$ & Direct & Allocate/ Traceable \\
\hline Shared Payroll & $\$ 810,847.00$ & Indirect & \# of Transactions \\
\hline Total & $\$ 4,657,152.50$ & & \\
\hline Non-Payroll expenses & $\$ 1,731,059.50$ & & \\
\hline
\end{tabular}

*These indirect costs are directly associated with payroll, composed of Unit Payroll and Shared Payroll. 


\section{APPENDIX 2}

\section{Per Unit Cost by Expense Category}

\begin{tabular}{|c|c|}
\hline Expense & Cost Per Driver Unit \\
\hline Advertising & $\$ 229.17$ \\
\hline Amortization & $\$ 0.2352$ \\
\hline \multicolumn{2}{|l|}{ Automobile Expense } \\
\hline Computer Maintenance & $\$ 1,779.36$ \\
\hline Depreciation & $\$ 771.06$ \\
\hline Donations & $\$ 500.00$ \\
\hline Education & $\$ 830.37$ \\
\hline Entertainment & $\$ 1,041.67$ \\
\hline Equipment Maintenance & $\$ 308.42$ \\
\hline Accounting Fees & $\$ 4.6731$ \\
\hline Legal Fees & $\$ 0.1514$ \\
\hline Other Professional Fees & $\$ 0.2911$ \\
\hline Insurance & $\$ 1.7467$ \\
\hline Medical Insurance & $\$ 4,166.07$ \\
\hline 401K Expense & $\$ 547.72$ \\
\hline Office Supplies & $\$ 4.0585$ \\
\hline \multicolumn{2}{|l|}{ Life Insurance } \\
\hline Payroll Taxes & $\$ 10,083.04$ \\
\hline Postage & $\$ 1.6114$ \\
\hline Courier & $\$ 0.5996$ \\
\hline Rent & $\$ 7,710.56$ \\
\hline \multicolumn{2}{|l|}{ Temp Salaries } \\
\hline Taxes \& Licenses & $\$ 0.2911$ \\
\hline Telephone & $\$ 2.3020$ \\
\hline Travel & $\$ 416.67$ \\
\hline \multicolumn{2}{|l|}{ Bad Debts } \\
\hline \multicolumn{2}{|l|}{ Unit Payroll } \\
\hline Shared Payroll & $\$ 37.3318$ \\
\hline
\end{tabular}


